\title{
近赤外分光法の緑茶品質管理への利用
}

佐々木製茶株式会社

原利男

(平成 7 年. 7 月 3 日受理)

\section{Quality Control of Japanese Green Tea by Near Infrared Spectroscopy}

\author{
Toshio HARA \\ Sasaki Seicha Co., Ltd
}

\section{1.はじめに}

緑茶の品質と相関の高い成分は全窒素と粗 繊維で,これらは原葉の熟度（生葉の硬さ）

と密接な関係がある。また, 緑茶の味を構成 する成分はカテキン類(タンニン), カフェイ ン及び遊離アミノ酸類（以下，アミノ酸と略 す）で，これら 5 成分を近赤外法で簡単に分 析できれば，緑茶の品質管理あるいは品質評 価に利用できる。

茶の全窒素, カフェイン, アミノ酸, テア ニン及びタンニンなどの近赤外法による分析 は, 池ケ谷らりにより検討され，その定量法が 確立されている。また, 近赤外法により茶の 主要成分を定量できる分析装置が市販され, 茶の品質評価への利用 ${ }^{2,3}$ が検討されている。

しかし, 測定データを茶の品質管理等に充 分活用する段階までには至っていない。これ は分析結果の整理及び利用方法等があまり検
討されていないからである。そこで, 近赤外 法により定量した茶成分值を，パーソナルコ ンピュータに取り込み，茶の品質管理等に利 用する方法4を検討したのでここれを中心に 紹介し，併せて研究面への利用についてもふ れてみたい。なお，本資料は第 10 回非破壊計 測シンポジウム (1994 年 11 月 18 日, つくば 市, 科学技術庁研究交流センター）で講演し た内容を, 加筆, 訂正したものである。

\section{2 . 近赤外法による茶成分の分析}

近赤外法による茶成分の分析方法について は, 池ケ谷らの詳細な研究報告 ${ }^{1) か ゙ あ る の て ゙, ~}$ それを参照されたい。

現在, 使用されている分析装置においては, 表 1 に示す茶の標準 (化学) 分析法5)を基準に して, 多くの試料を測定し, 線形重回帰分析 等の統計的手法で検量線を作成する。した がって, 近赤外法の分析精度（表 1 に示す予

表 1 茶の標準分析法と近赤外法の予測標準誤差

\begin{tabular}{|c|c|c|}
\hline 分析項目 & 標準分析法 & 予測標準誤差 (\%) \\
\hline 水 & 常圧 $100^{\circ} \mathrm{C}$ 乾燥法 ${ }^{5)}$ & 0.15 \\
\hline 全 窒 菜 & セミミクロケルダール法5) & 0.1 \\
\hline タン $=2$ & 酒石酸鉄比色法5) & 0.5 \\
\hline カフェイン & HPLCによる定量5) & 0.15 \\
\hline$ア ミ ノ$ 酸 & ニンヒドリン呈色法5) & 0.3 \\
\hline 粗 瀻 維 & Van Soest改良法 ${ }^{6)}$ & 1.0 \\
\hline
\end{tabular}

注：近赤外法による予測標準誤差は静岡製機做。茶成分分析計のカタログから引用。 
測標準誤差）は標準分析法とだいたい同じ精 度となる。

一例として，静岡製機（株）・茶成分分析計 GT -8 で茶の全窒素及びタンニンを定量 し，化学分析值と対比した結果を図 1 及び 2 に示す。これによると，茶の全窒素は近赤外 法で非常によい精度で定量でき，予測標準誤 差は $0.1 \%$ 以下で，ケルダール法による分析 精度とほほ同じと考光られる。

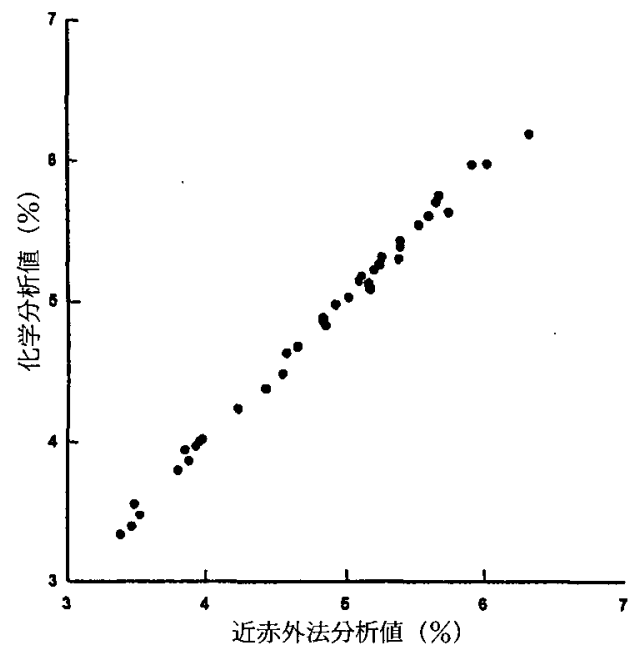

図 1 煎茶の全空素の化学分析值と近赤外法分 析值の対比

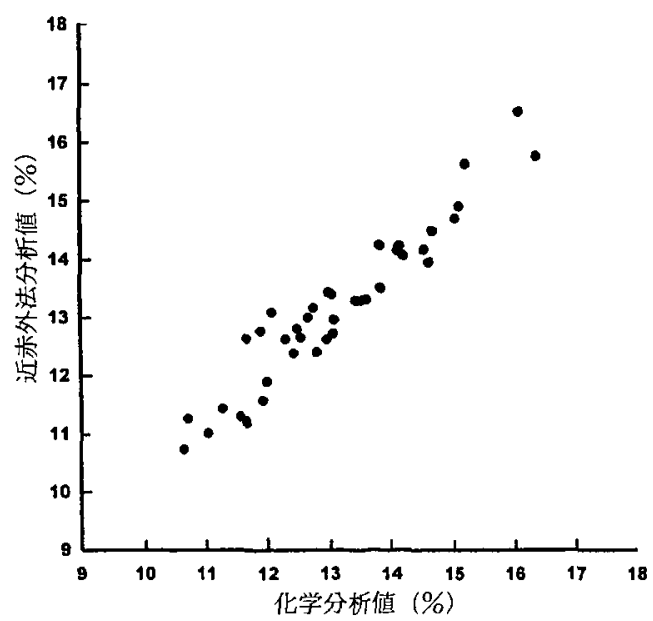

図 2 煎茶のタンニンの化学分析值と近赤外法 分析値の対比
一方，タンニンは近赤外法による定量值が かなりバラつくが、標準誼差 $0.5 \%$ 以内であ る(図 2 )。タンニンについては，比色分析を 採用していることから標準分析法もこの程度 のバラツキがあり，分析精度としては問題は ない。

近赤外法による茶の分析値として問題があ るのは水分と粗瀻維で, 前者は常圧 $100^{\circ} \mathrm{C} \cdot 3$ 〜 5 時間乾燥法を標準にしているので，少し 低い水分值となる。今後，水分の定量につい ては乾燥温度を再検討する必要があると思 う。

また,近赤外法による茶の粗繊維の定量は, 標準法として中性デタージェント溶液 ${ }^{6}$ を用 いて，茶粉末を煮沸し，細胞内容物を洗い流 して, 残渣を測定している。一般に食品分析 法では，この残渣から灰分を除いているが， 近赤外法による茶の粗繊維は灰分を含んだ数 値を使用している。茶の品質指標の一つとし て利用するにはよいと思うが，成分值として は洃分を除く必要があると考える。

\section{3 . 近赤外分析装置と分析システムの構成}

筆者が使用している近赤外分析装置と分析 システムの構成を簡単に紹介する。

\section{1 近赤外分析装置}

静岡製機 (株) - 茶成分分析計 GT-8 を使 用した。本装置は茶の水分, 全窒素, 粗繊維, タンニン，カフェイン，アミノ酸及びテアニ ンなどの主要成分を近赤外法で定量する分析 計である。また, 本装置で䒩の主要成分を分 析するには，コーヒーミル等で一定時間粉砕 した茶（粉末）をセルに詰めて測定する。た だし，茶の水分と全窒素を迅速に測定したい 場合には，茶のままセルに詰めて測定できる 検量線も作成されている。製茶工程管理に水 分を測定する場合には都合がよい。

\section{2 分析システム}

分析システムは茶成分分析計(静岡製機(株) - $\mathrm{GT}-8)$ ） FA パーソナルコンピュータで 構成し, 分析計で測定した各成分值は R S - 


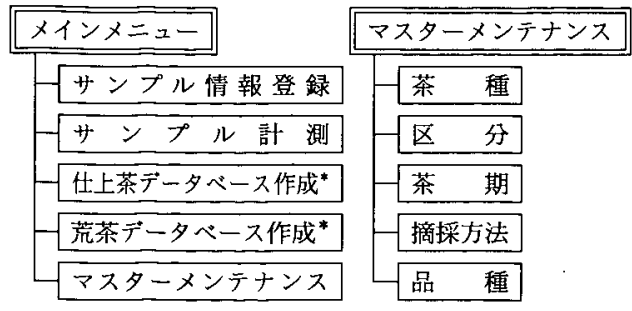

図 3 茶分析システムメニューの概要

* 計測データファイルをロータスー 1-23 のデータファイルに変換する。

$232 \mathrm{C}$ を通してパソコンに取り込むようにし た。システムメニューの概要を図 3 に示す。 メインメニューから実行したい処理を選択す る。まず，サンプル情報登録処理を選択し， 分析前に分析試料の情報をパソコンに記録す る。この場合，よく使用する情報はマスター メンテナンスにあらかじめ登録しておき，常 時パソコンに取り込めるようにした。

次に，サンプル計測に移る。この場合，1 回に 15 点のサンプルを登録し, 連続して分析 できるようにした。分析した一連のデータ ファイルは荒茶及び仕上茶の別に表計算ソフ トのワークシートに移し，グラフ表示等で比 較できるようにした。

\section{4. 製茶工程管理への利用}

茶の流通経路を最も簡単に考えると, 図 4 に示すように茶園で生産された生葉は, 荒茶 工場で水分約 $5 \%$ の荒茶に加工され，それを 産地問屋が購入し，荒茶のまま冷蔵する。産 地問屋では需要に応じて，水分 $2 \sim 4 \%$ の仕 上茶に加工，包装して消費値小売り店に販売 する。したがって, 緑茶の取引は荒茶と仕上
茶に区別され，加工工程は荒茶の製造と仕上 茶の加工に大別される。

荒茶の製造は, 水分約 $80 \%$ の生葉を蒸し て, もみながら乾燥するので, 茶葉の水分管 理は重要である。一番茶の最初は機械の運転 が不慣れで，荒茶工場から乾燥不良の製品が 産地問屋に持ち込まれることが時にある。こ れについては, 手触りでもわかるが, 近赤外 法で水分を測定すれば，分析值(表 2)をもっ て荒茶工場に乾燥状態の改善を指導できる。

表 2 乾燥不良の荒茶測定例 '(1993)

\begin{tabular}{cccc}
\hline 工場 & 水分 $(\%)$ & 全窒素 $(\%)$ & 乾燥程度 \\
\hline $\mathrm{A}$ & 4.6 & 5.8 & 良好 \\
$\mathrm{B}$ & 6.9 & 5.7 & 不良 \\
$\mathrm{C}$ & 5.4 & 5.7 & 良好 \\
\hline
\end{tabular}

注： $\mathrm{A} ， \mathrm{~B}, \mathrm{C}$ とも一番茶の手摘み製品。

仕上茶については, 図 5 に示すように価格 の高いものほど水分が多いが，これは火入れ の強度のちがいによるものである。とくに, 新茶の時期には新鮮香を重要視するので, 火 入れが弱くなりがちである。火入れ前後の茶 の水分を測定し，水分が $3 \sim 4 \%$ となるよう に火入れ工程を管理する。本報告に使用した 仕样の機種（静岡製機（株）・茶成分分析計 $\mathrm{GT}-8)$ ）茶のままセルに詰めて水分を測 定できるので，工程管理上，都合がよい。

\section{5. 品質管理への利用}

\section{1 荒茶成分の特性調查}

荒茶については, 工場別に茶成分の経時変 化を調べ, 各茶期ごとの分析値を比較すれば, その工場の茶の品質特性がよくわかる。

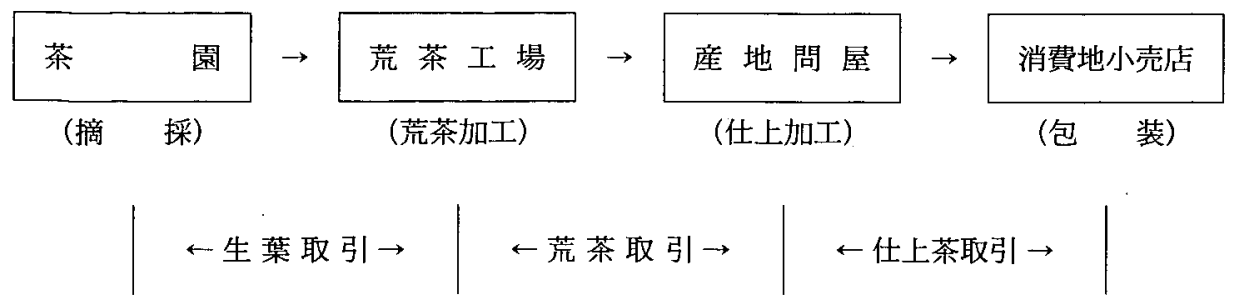

図 4 茶の流通経路 
一例として，小笠製茶 (株)・で 1994 年に 製造された一番茶と二番茶を毎日採取して， 各茶期の経時的な成分変化を比較した結果の うち，全窒素とアミノ酸含有量を比較した結 果を図 6 に示す。

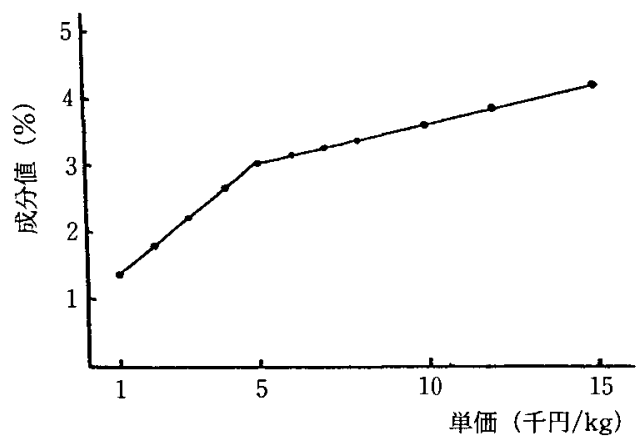

図 5 価格別煎茶の水分含量（1992）

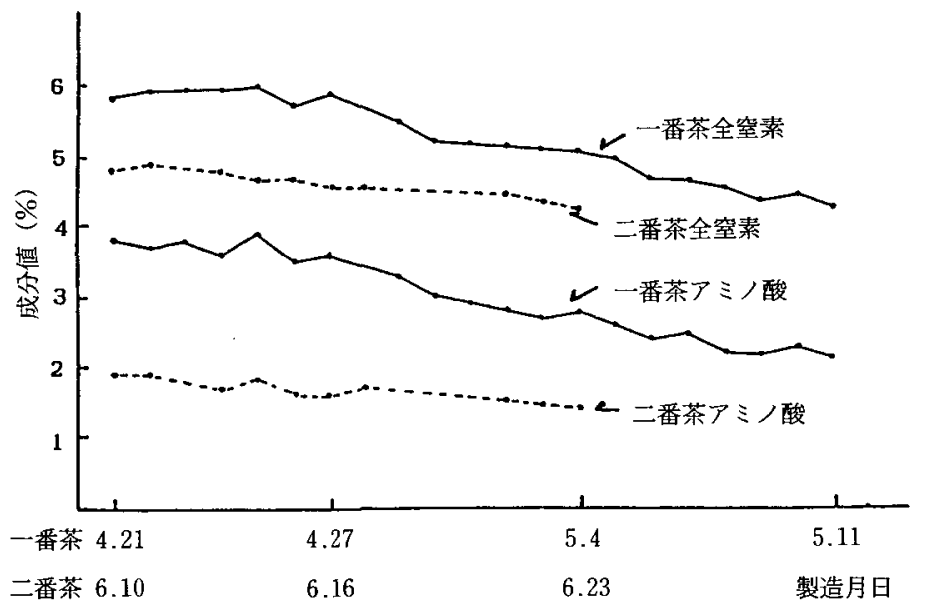

図 6 荒茶の全至素とアミノ酸含有量の比較 (1994)
これによると, 一番茶の前半は二番茶より 全窒素含有量が高かったが，一番茶の後半に なると二番茶と同じ全窒素含有量になった。 しかし, 香味は一番茶後半でも二番茶よりよ く, 高く取り引きされる。したがって, 全窒 素含有量で一番茶と二番茶を通して品質評価 をすることは困難である。

アミノ酸含有量は二番茶より一番茶が全体 的に多く，一番茶後半になっても減少が少な く, 一番茶末期のものでも二番茶よりアミノ 酸含有量は高かった。このようにアミノ酸含 有量は品質をよく反映しており，一，二番茶 を通して品質指標となることがよくわかる。

図には示さなかったが，タンニン含有量は 一番茶より二番茶に多く, カフェイン含有量 は一番茶と二番茶の差が少なかった。粗纎維 は全窒素の逆の傾向を示した。 次に，茶の味を構成する夕 ンニン，カフェイン及びアミ ノ酸の成分バランス (以下, 主要成分バランスと略す）を 調べた結果を表 3 に示す。

これによると, 一番茶及び 二番茶とも摘採時期の早いも のほど, タンニンの割合が少 なく,アミノ酸の割合が多い, とくに，この傾向は一番茶に 大きく認められた。また，一 番茶は二番茶に比較して, 夕 ンニンの割合が少なく、アミ ノ酸の割合が多かった。

表 3 荒茶の主要成分バランス（1994）

\begin{tabular}{|c|c|c|c|c|c|c|}
\hline 茶 & 期 & 製造月日 & タンニン & カフェイン & アミノ酸 & 備 \\
\hline & & 4.21 & 67.3 & 15.7 & 17.0 & 手摘み \\
\hline & & 4.27 & 68.3 & 14.7 & 17.0 & $n$ \\
\hline & & 4.30 & 70.5 & 14.0 & 15.5 & はさみ \\
\hline & & 5.10 & 74.4 & 12.0 & 13.6 . & $n$ \\
\hline & & 6.10 & 77.1 & 14.0 & 8.9 & $n$ \\
\hline & & 6.16 & 78.8 & 13.3 & 7.9 & $n$ \\
\hline & & 6.23 & 79.8 & 13.0 & 7.2 & " \\
\hline
\end{tabular}

注：タンニントカフェイントアミノ酸 $=100$ 


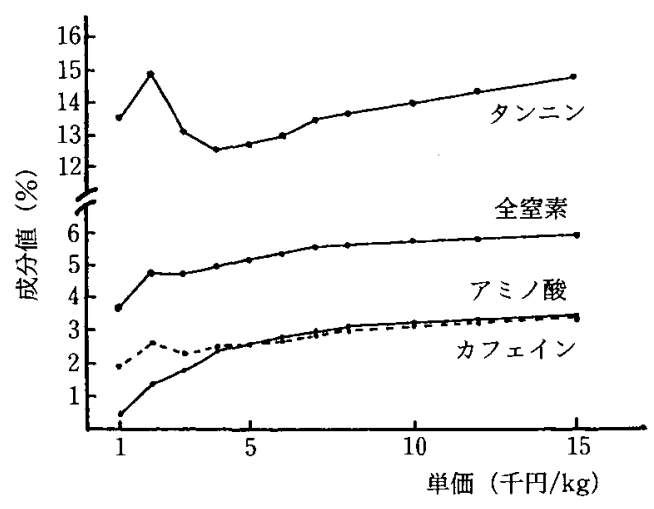

図 7 仕上茶の成分比較 (1992)

カフェインの割合は一番茶と二番茶にあま り差が認められなかった。

\section{2 仕上茶成分の特性調查}

品質と成分の関係を調べるため, 仕上茶に ついて価格別に茶成分の特性調查を行った。

一例として，佐々木製茶(株)・直売部で 1992 年 10 月から 12 月にわたって市販した, $\mathrm{kg}$ 単 価 1,000 円から 15,000 円までのサンプル 11 点を毎月集めて,分析した結果を図 7 に示す。

これによると, 全窒素含有量は従来からい われているように, 価格の高いものほど多く なっているが，この調査では 2,000 円 $/ \mathrm{kg}$ と 3,000 円 $/ \mathrm{kg}$ のものは差がない。この点につ いては荒茶のところで説明したように二番茶 $(2,000$ 円 $/ \mathrm{kg})$ と一番茶末期 $(3,000$ 円 $/ \mathrm{kg})$
のものは, 全窒素含有量にあまり差がないた めと考えられる。

アミノ酸含有量は仕上茶の価格の上昇に 伴って多くなり, 向井ら7の報告にもあるよ うに煎茶の品質指標の一つとして利用できる ことが認められる。

タンニン含有量については，4,000 円/ $\mathrm{kg}$ 以上のものは価格の上昇に伴って含有量が多 くなった。これに対し, 3,000 円 $/ \mathrm{kg}$ 以下のも のは特異的な傾向を示しており，このうち， 2,000 円 $/ \mathrm{kg}$ の茶は二番茶でタンニン含有量 が最も多い。次いで, 1,000 円 $/ \mathrm{kg}$ のものが多 く，これは三番茶と四番茶の混合品であるの で,このような傾向を示したものと思われる。 カフェイン含有量は全窒素とほほ同じ傾向を 示していた。

次に，仕上茶の主要成分バランスを調べた 結果を表 4 に示す。これによると, 価格の下 がるに従ってタンニンの割合が多くなり，ア ミノ酸の割合が減少した。とくに，この傾向 は 3,000 円 $/ \mathrm{kg}$ 以下のものに強くなった。ま た，カフェインの割合も価格の下がるに従っ て少し減少したが，アミノ酸のように大きな 変化はなかった。

このように仕上茶については，価格あるい は銘柄別に分析值を整理しておけば，いろい ろと利用できる。たとえば，消費地の販売業 者からこのような見本の茶が欲しいと, 現物 を提示された場合，官能検査で品質を調べる とともに，近赤外法で分析すれば，どの価格

表 4 仕上茶の主要成分バランス（1992）

\begin{tabular}{cccc}
\hline 価格 $($ 円 $/ \mathrm{kg})$ & タンニン & カフェイン & アミノ酸 \\
\hline 15,000 & 68.6 & 15.7 & 15.7 \\
10,000 & 68.8 & 15.4 & 15.8 \\
8,000 & 69.2 & 15.2 & 15.6 \\
6,000 & 70.3 & 14.6 & 15.1 \\
4,000 & 72.0 & 14.2 & 13.8 \\
3,000 & 76.1 & 13.4 & 10.5 \\
2,000 & 78.8 & 13.8 & 7.4 \\
1,000 & 84.9 & 11.9 & 3.2 \\
\hline
\end{tabular}

注：タンニントカフェイントアミノ酸 $=100$ 
の茶かすぐわかる。また，分析記録をとるこ とによって，販売あるいは包装した商品の手 違い等は防止できる。

\section{6. 研究面への利用}

国公立の試験研究機関で優良茶品種を選別 する場合，育成した多くの系統の品質を調べ る必要がある。これには従来から小型製茶機 で茶を作り，官能検查で品質を調べていた。 官能検查には個人差も含まれるため判定結果 の客観性が問題になる場合がある。官能検查 と並行して近赤外法で茶の主要成分を分析す れば, 茶の品質のよしあしが簡単に推定でき るように思う。

また, 1993 年は全国的な天候不順により, 静岡の茶産地においても, 凍霜害, 一番茶摘 採時期のおくれ等が生じ，例年より味が薄い 等の現象が認められ, 茶の品質も低下した。 この年の一番茶を近赤外法で分析し, 1994 年 の一番茶と比較すると, 1993 年は一番茶前半 のものが全窒素とアミノ酸含有量が少し低い ことが諗められた。このように毎年茶の分析 記録を取って抢けば，その年の気象条件，あ るいは栽培管理と茶の品質の関係が検討でき る。

\section{7. 今後の課題}

今後多くの分析データが整備され, 分析值 と品質との関係が明らかになれば, 近赤外法 で茶の品質を判別できる手法等が開発され， 茶の成分分析值で, 消費者にその品質が説明 できるようになると考える。また, タンニン, カフェイン, アミノ酸等の成分バランスを利 用して, 茶の味見計的な利用方法が開発され る可能性もある。そのためには近赤外法の利
用方法つまりユースウエアについて，国公立 の試験研究機関, 装置メーカー, 茶商工業者 等が共同研究をすることが望ましい。

なお，近赤外法で信頼できる分析值を得る ためには，基準となる標準分析法の検討と， 定期的に行う測定システムの校正に使用する 標準サンプルの作成等が不可欠であり，国の レベルでの検討が必要と考える。

\section{8. 引用文 献}

1）池ヶ谷賢次朗・高柳博次・阿南豊正・岩 本睦夫・西成勝好・趙来光 (1988)：近赤外 分光法による前茶および抹茶の全窒素, 力 フェイン, 全遊離アミノ酸類, テアニン, タンニンの定量. 野菜茶試研報, B (金谷), 第 2 号, 47〜90.

2) 後藤 正(1992)：近赤外法による茶生葉 及び荒茶の成分分析と品質評価に関する研 究. 茶研報 $76,51 \sim 61$.

3) 堀江秀樹 - 深津修一 - 向井俊博 - 後藤哲 久 (1992)：官能検査と近赤外分光分析法に よる市販煎茶の品質評価. 茶研報 76, $39 \sim 44$.

4）原 利男-松村正弘 (1994)：近赤外分光 法による緑茶の成分特性調查. 茶研報 79 , $25 \sim 30$.

$5 ）$ 池ヶ谷賢次朗・高柳博次・阿南豊正 （1990）：茶の分析法. 茶研報 $71 ， 43 \sim 74$.

6）食物瀻維の定量法(1989)：小原哲二郎他 編, 食品分析ハンドブック, 建帛社, 東京, pp 252 253.

7) 向井俊博・堀江秀樹・後藤哲久 (1992)： 煎茶の遊離アミノ酸と全窒素の含量と価格 の関係について。茶研報 $76,45 \sim 50$. 